\title{
Development of the Business Model of a State-owned Bank to Support Financial Inclusion in Indonesia
}

\author{
Wicaksono Sarwo Edi*, Marimin, Arief Daryanto, Imam Teguh Saptono \\ IPB Business School - Bogor Agricultural University \\ SB-IPB Building, IPB Campus Gunung Gede, \\ Pajajaran Street, Bogor, Indonesia \\ ${ }^{*}$ Corresponding author's email: wicaksono.sarwoedi [AT] yahoo.com
}

\begin{abstract}
Banking business in Indonesia has proliferated, but the existing business model seems not responding to the need for financial inclusion development yet. State-owned banks which act as development agents require to provide more attention to develop useful business models for financial inclusion. The parties involved in the financial inclusion business are very diverse. The interests of each party are also complexly interrelated. We use interpretive structural modeling (ISM) and analytic network process (ANP) to parse the problems and develop a map of clear correlations between various complex elements so that they can be transformed into visible models. This method utilizes experts' knowledge and experience to understand complex problems and then build multilevel structures and determine the dominant factors of the system. There are many experts involved in research; who are consist of top-level practitioners from the bank, experts from the bank's competitor, financial technology experts, expert from the regulator. The research covers five areas or elements, i.e. the element of requirements, constraints, objectives, possible changes, and actors. The resulting outputs are (1) driving power-dependence matrix sub-elements, (2) ISM structural model that describes the map of sub-elements level and how sub-elements influence each other (3) ANP prioritization by subelement per cluster. From these three outputs, we get the primary keys of each element that plays the most significant role in developing the model. This study concludes that the primary keys in developing the business model for the bank are: shared vision and collaboration between units, IT support, expand to micro, development of new ideas, meeting customer needs-anticipating their pain-gain, convert fix to variable cost, eliminating silo mentality, and the roles Directors. And also forming new forming new division, when the bank decided to implement the business model.
\end{abstract}

Keywords - analytical network process, complex problems, interpretive structural modeling, experts' judgement

\section{INTRODUCTION}

Financial inclusion is not a linear measure for the welfare of a country or an area, but the level of financial inclusion is often used as a measurement of the success of a country to improve welfare. The World Bank defines financial inclusion as access for individuals and businesses to useful and affordable financial products and services, transactions, payments, savings, credit and insurance, delivered in a responsible and sustainable way. [1] stated that the existence of a family economic welfare is strongly supported by access to financial services. With this access, low-income people can meet their needs and can overcome fluctuations in the existing economic conditions, and then they can set aside a portion of their income to be saved. [2] notion that there is a negative correlation between the increasing of access to financial services and the number of destitute people, even though the correlation is not robust. A negative correlation is also found in the relationship between the level of financial access and the Gini index or the level of inequality. It means that the higher the financial access, the more inequality will decline.

According to [3], the Government of Indonesia earnest about developing financial inclusion. The bank which assigned to play as the leading part is BRI. These financial inclusion activities have been carried out since the 1970s, primarily through the development of microfinance. However, based on World Bank data, Indonesia's financial inclusion level is still relatively low. Based on 2014 data stated by [4] and [5], Indonesia's adult population aged 15 years and over who have any account reaches only $36 \%$, still far from the level of World financial inclusion which reaches $62 \%$. Other data said that Indonesia's adult people who have loans reach $56.57 \%$ of the population, but those who borrow from formal financial institutions are only $13.14 \%$ so that $43.43 \%$ still borrow from non-formal financial institutions. Indonesia's adult people who save their money reach $69.30 \%$ of the population, but only $26.56 \%$ of those save their savings in formal institutions.

The bank discussed in this paper is an Indonesian state-owned commercial bank. As a state-owned company, the bank is required by law to carry out its operations based on two goals. Firstly, to achieve growth and profit target. Secondly, at the same time, the bank has to play a role as agents of development, i.e. to develop weak economic entrepreneurs and to prosper the community. Based on 2012-2016 internal data, the bank experienced extraordinary credit growth above the industry's average. On the other hand, there was a significant decrease in the number of debtors, especially in the micro and small segments. This resulted in an increase in the average of micro and small loans per debtor, from IDR 61 million 
to IDR 186 million per debtor in 2016. Regarding the banks' role as an agent of development, the increase in an average loan for this segment is not expected. Even though the average value is still within the range of regulation, i.e. the maximum loan of IDR 500 million, it is getting away from the maximum loan for microcredit, which is IDR 25 million. This value is also far above other the domestic banks as a benchmark, which the average loan per debtor was IDR 21 million.

In the area of savings and transactions, the bank also shows an unexpected performance. Even though the bank has expanded and brought the bank services closer to people through the use of agents, its effectiveness is still low. Since 2015 - 2017, the number of agents has been proliferating and reaching almost 70000 agents, but the transaction activities still very limited. The transaction activities reached only 2.5 million transactions per month. Since there are 4.8 million accounts managed by the agents, it means that each account transacts less than one time per month. On average, each agent transacts only 42.27 times per month, with a transaction volume of IDR 13.45 million per month. The average assets managed by each agent are also still low, i.e. 69.6 accounts per agent and third-party funds of IDR 8.07 million per agent. In the benchmark country, such as Kenya, transactions done by the agents were 15 to 25 times higher, both in terms of the number and value of transactions. The low number transaction impacted low fees or income received by the agent. Subsequently, agents cannot cover operational costs, and they cannot work as expected.

The development of the financial inclusion business model cannot be separated from the concept of developing mobile banking as proposed by [6], as well as the development of international remittances that strongly supported the increase in GDP delivered by [7]. One of the main issue of financial inclusion is microfinance which is concluded by [8].

The bank's performance in the micro and small segments, consist of credit, savings and payment transactions, as described above looks not as expected. One of the main causes that drive the bank performance below expectation is ineffective business model. [9] mentioned that the business model is a systemic perspective on how to do business. [10] and [11] also suggest that business models are important sources for firms to obtain sustainable competitive advantages in the new era. This paper aims to answer two questions that arise, i.e.: (1) how we develop the business model suitable for the bank to support financial inclusion. (2) which part of the business model is the main key in driving the business model.

\section{BUSINESS MODEL FRAMEWORK}

Discussions among experts, conduct in [12] proposed an initial financial inclusion business model on the BMC framework shown in Figure 1. The BMC framework, introduced by [13], consists of 9 building blocks, i.e., Customer Segments, Channels, Relationship, Value Proposition, Revenue Streams, Key Resources, Key Activities, Key Partnerships, and Cost Structures. Further analysis applies the ISM and ANP methods to validate and determine the implementation strategy.

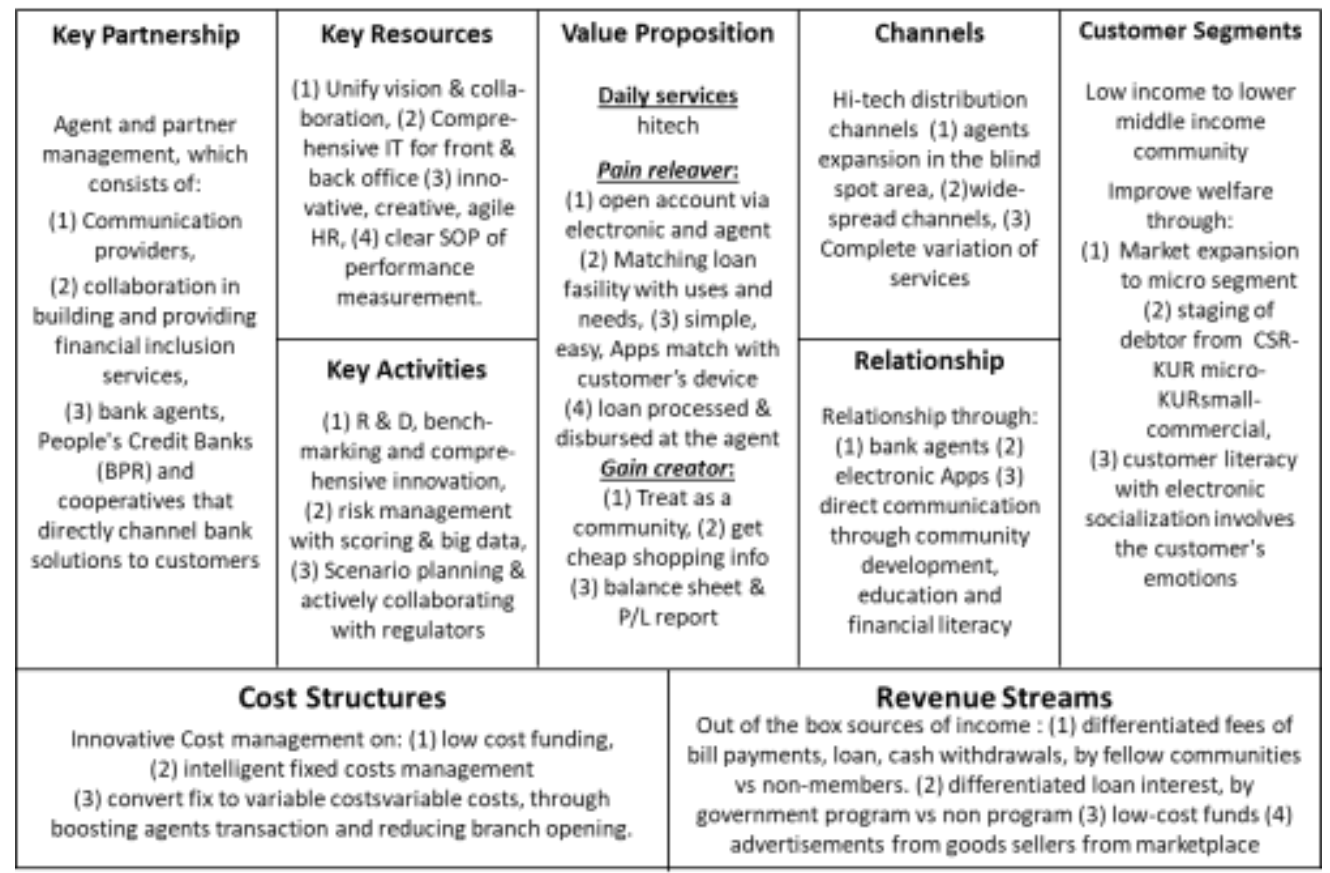

Figure 1. Framework of Financial Inclusion Business Model

The business model needs to be attached with an implementation strategy, which explains the steps of prioritization. Prioritization is needed because it is uncertain that all business model project requirement can be fulfilled. Important aspects 
need to prioritize, as well as identifying key aspects that become the point of leverage for the projects implementation of the business model.

\section{ANALYTICAL TOOLS}

\subsection{Interpretive Structural Modeling (ISM)}

Interpretive Structural Modeling (ISM), introduced by [14], is a useful methodology for dealing with complex problems. With this methodology, we can develop a map of relations between various elements involved in complex situations. A mental model that is not visible is transformed into a more visible system model. This modeling method was developed to deal with strategic and policy planning [15].

This ISM modeling technique utilizes and setting forward experts' knowledge and experience to decompose complex problems or system into sub-systems and then build multilevel structures to determine the dominant factors in implementing the system [16]. [16,17] also show that modeling with ISM has essential characteristics, including: (1) it is an interpretative method, so whether and how relationships between elements are determined based on judgment. (2) the relationship between elements is displayed in the digraph model, (3) the model is a structure based on mutual relationships, (4) this model creates levels (orders) and direction of relations between sub-elements. (5) the process of model development is a learning process for groups and individuals also.

ISM methode start with the building of Structural self-interaction matrix (SSIM). It is built from the agreement of experts using various methods including brainstorming, focus group discussion, or other methods. Initially experts from practitioners, competitors, substitution service providers, and regulators were asked to determine what elements to consider in the study. Then the experts are asked to identify the contextual relationships between the sub elements in each of the elements studied. The contextual relations of the two sub-elements, i.e. the sub-elements " $i$ " and the sub-elements " $j$ " that is in the element, can occur in four forms and each is given a symbol. The four types of contextual relationships between the two sub-elements ( $i$ and j) are: (1) V if the sub-elements $i$ affect the sub-elements j, and not vice versa, (2) A if the subelements $\mathrm{j}$ affect the sub-elements $\mathrm{i}$, and not vice versa, (3) $\mathrm{X}$ if sub-elements $\mathrm{i}$ and $\mathrm{j}$ influence each other, (4) $\mathrm{O}$ if subelements $i$ and $j$ have no influence on each other. The final SSIM result is an agreement or consensus of experts.

Reachability matrix is the result of a conversion from a structural self-interaction matrix. SSIMs that use four symbols, i.e. $\mathrm{V}, \mathrm{A}, \mathrm{X}$, and $\mathrm{O}$, are converted into a matrix consisting of binary numbers 1 and 0 . The conversion is set as follows: (1) if cell $(i, j)$ contains the symbol $V$, then reachability matrix cell $(i, j)$ is filled with numbers 1 and cell $(j, i)$ filled with numbers $0,(2)$ if cell $(i, j)$ contains symbol $A$, then in reachability matrix cell $(i, j)$ is filled with numbers 0 and cell $(j, i)$ is filled with number $1,(3)$ if cell $(i, j)$ contains an $X$ symbol, then in reachability matrix cell $(i, j)$ is filled with numbers 1 and cell $(j, i)$ filled with number $1,(2)$ if cell $(i, j)$ contains the symbol $O$, then in the reachability matrix cell $(i, j)$ is filled with numbers 0 and cell $(\mathrm{j}, \mathrm{i})$ filled with number 0 . Then the transitivity of the reachability matrix is checked. The concept of transitivity is that if $\mathrm{A}$ is related to $\mathrm{B}$, and $\mathrm{B}$ is related to $\mathrm{C}$, then $\mathrm{A}$ should be related to $\mathrm{C}$. If there is transitivity, then the cell contents associated need to be adjusted from 0 to 1 .

The process above and the next steps can be done with the help of available software. The output of the ISM process is a two-axis matrix which shows the dependence level and driving power level. The matrix is divided into four quadrants, i.e.: (1) autonomous, with a low level of dependence and low driving power. The sub-elements in this quadrant have only a few relationships, although they may be a strong relationship, (2) dependent, with a low level of driving power and high dependence. Sub-elements in this quadrant are non-free sub-elements, (3) linkage, with a high level of driving power and dependence. Each change in the sub-elements in this quadrant will have an impact on the sub-elements at a higher level and then produce the opposite effect on it, (4) independe, with a high driving power level but a low dependency level. Subelements in this quadrant are free variables.

The next output is an ISM structure model that explains the level map of each sub-element and how a sub-element is influenced and influences other sub-elements. Based on this model, give notions which sub-elements are prominent and can act as leverage points in the system.

\subsection{Analytic Network Process (ANP)}

ANP analysis utilizes the knowledge and experience of experts in describing complex problems through focus group discussions and expert judgment. Analytic Network Process (ANP) is a relative measurement method to produce composite priority ratios of the individual ratio scale. The method is a relative measurement of the influence of interacting elements in control criteria. With this method, we can treat dependence and feedback system to capture and combine tangible and intangible factors. The discussion about ANP cannot be separated from the Analytic Hierarchy Process (AHP), ANP is the generalization of AHP [18]. Better than AHP, the decision-making process in ANP is carried out without the need to view the independence of elements at a higher level towards elements at lower levels, as well as the independence of elements at a level. ANP uses networks without having to set levels as in the hierarchy in AHP. 
In the AHP hierarchy, there is a goal, several levels of elements, and relationships between elements, which are only oriented from a high level to a lower level. As for the network, ANP elements are placed in the cluster, and the relationship can affect the outer dependence between clusters, or the dependence between elements in one cluster in the form of inner dependence. The main concept of ANP is the influence, whereas in AHP is preference. It can be said that AHP is a special case or part of ANP. In AHP and ANP analysis, the comparison between criteria is carried out by pairwise comparison. The fundamental comparison scale used in judgment can be seen in Table 1.

Table 1. The fundamental comparison scale

\begin{tabular}{cl}
\hline Scale & Description \\
\hline \hline 1 & Equally important \\
\hline 3 & The level of importance of one to another is moderate \\
\hline 5 & The level of importance of one to another is strong \\
\hline 7 & The level of importance of one to another is very strong \\
\hline 9 & The level of importance of one to the other is extremely strong \\
\hline $2,4,6,8$ & Values midway between odd scales \\
\hline
\end{tabular}

The pairwise comparison method allows inconsistencies in the transitivity relationship of preference. If $x>y$, and $y>z$, then it should be $x>z$, so if $x=2 y$, and $y=3 z$, then it should be $x=6 z$. [19] recommends inconsistencies in each pairwise comparison group with a maximum of $10 \%$. If the inconsistency exceeds this value, then the expert will reconfirm.

\section{METHODOLOGY}

\subsection{ISM Analytic to determine the driving sub-elements of the business model}

Research to develop this financial inclusion business model was conducted using the interpretive structural modeling (ISM) method, which put forward expert judgment. We conduct focus group discussions among experts, where experts analyze models within the BMC to determine the ISM structure. The data was collected during focus group discussion. In the development of a structure for defining relationships between elements with the ISM method, [20,21] mentions programs can be structured into 9 elements, i.e. (1) needs or requirements, (2) constraints or problems, (3) possible changes, (4) objectives or goals, (5) targets or indicators, (6) activities, (7) actors, institutions or stakeholder, (8) affected segments, and (9) effectiveness. In this study not all elements are used, but the elements are chosen according to their needs.

Experts agreed to use five of the nine elements, i.e. elements of requirements, constraints, objectives, possible changes, and actors. It means that the experts conclude that knowing the ISM structures of these 5 elements, then the steps of the business model implementation can be determined. The structure will show key sub-elements and the relationship between sub-elements each other. Potential error in the ISM process that utilizes contextual relations questions is transitivity. Software will automatically corrects the reachability matrix, if transitivity occur. Subsequently, for each of the five selected elements, sub-elements are specified.

The element of requirements contains sub-elements needed to build an optimal business model. A good business model needs the existence of these sub-elements. This element includes ten sub-elements, as follows: (E1) similarity of vision and collaboration between Units, (E2) availability of SOPs of fair performance recognition and key performance indicators (KPI), (E3) availability of provisions for revenue / cost sharing and profitability reliable report, (E4) elimination of silo mentality, (E5) mutually beneficial cooperation with network, system, solution and fintech service providers, (E6) availability of reliable external distribution channels, including bank, BPR and cooperative agents, (E7) adequate information technology support in various areas, (E8) adequate customer financial literacy, (E9) opportunity to benchmark, and the availability of relevant knowledge and ideas, (E10) availability of customer research data, suppliers and competitors.

The element constrains contain sub-elements which can become obstacles, when we want to build an optimal business model. This element includes thirteen sub-elements, as follows: (E1) customer financial literacy is still low, (E2) assumption in the community that program credit is a grant, (E3) customer data is less accurate and its validity is low, (E4) customer segment small and micro are very spread out, (E5) capability of external distribution channels, i.e. bank agents, rural banks, and cooperatives, which are still limited, (E6) challenges from competitors and substitution of solutions such as fintech and others, (E7) there is less similarity in common vision and collaboration within units, (E8) there is still a silo mentality, (E9) SOP recognition of performance and key performance indicators that have not been supported, (E10) the provision of revenue / cost sharing which is considered unfair, (E11) there is a required procedure which must comply with the regulation, for example knowing your customer-KYC, (E12) information technology support that has not been optimal for all kind of services, (E13) clarity regarding the sustainability of government programs, including interest subsidies, non-cash food aid. 
The element of objectives contains list of objectives that want to achive as we build an optimal business model. This element includes twelve sub-elements, as follows: (E1) meets customer expectations (easy to reach, cheap, fast, and not complicated), (E2) creates a climate of mutually beneficial cooperation between banks and external distribution channels, (E3) increased portfolio of small and micro loans, (E4) increasing third party funds and transactions, (E5) increasing number of deposit and credit accounts, (E6) decreasing credit risk, (E7) formation of close-loop transaction, (E8) implementation of effective and efficient transactions, among others through the establishment of a market place, (E9) the creation of a safe transaction climate against fraud and external and internal crimes, (E10) increased effectiveness of bank agents (value of third party funds / agent, number of transactions / agents), (E11) the creation of a framework for improving the welfare of small and micro segments, (E12) increasing customer financial literacy.

The element of possible changes contains list of changes that can be done when we build an optimal business model. This element includes twelve sub-elements, as follows: (E1) encourages the equalization of vision and coordination and collaboration between Units, (E2) establishes SOPs of recognition of performance and fair key performance indicators, (E3) specifies the terms of revenue / cost sharing, (E4) elimination of silo mentality, (E5) designing easy services, inexpensive, fast, not complicated, (E6) designing close-loop transaction services, (E7) designing comprehensive services between third party funds, loans and payment transactions, (E8) designing a market place for more effective and efficient transactions, (E9) designing debtor acquisition methods with faster processes and reducing credit risk, (E10) increasing the effectiveness of external channels (bank agents, BPRs, and cooperatives), (E11) increasing customer financial literacy, (E12) increasing the awareness of debtors to record transactions through a simple and attractive IT system.

The element of actors contains stakeholders who affects is affected by when we build an optimal business model. This element includes fourteen sub-elements, as follows: (E1) Directors, (E2) Strategic Planning Division, (E3) Product Development Division, (E4) Small-Micro Business Division, (E5) Network and Service Division, (E6) Institutional Relations Division, (E7) Electronic Banking Division, (E8) Small-Micro Credit Risk Division, (E9) Small-Scale RegionalBranch Office, (E10) Government/ Ministry, (E11) Regulators (BI / OJK) ), (E12) Network suppliers, systems and fintech companies, (E13) External distribution channels (agents of banks, BPR, cooperatives), (E14) Customers.

\subsection{ANP Analytic to Prioritize Sub-elements for Business Model Implementation}

ANP structure is developed from the elements of 9 blocks business model canvas, which are grouped into 4 clusters. A cluster, contains of alternative strategies for implementation, is added. Grouping of 9 blocks into 4 clusters is in accordance with the initial theory of BMC [22], grouping as follows: (1) clusters Customer Relationship includes Customer segments, Channels and Relationship, (2) Cluster Product contains Value Proposition, (3) Cluster Infrastructure Management includes Key Resources, Key Activities and Key Partners, and (4) clusters of Financial Aspects include revenue streams and cost structure. The structure of the ANP is shown in Figure 2.

Using the ANP method, priority of sub-elements and the weight of the priority will be obtained. Thus, it can be determined which sub-elements must be implemented first, adjusted to the availability of resources. Similar with ISM process, the study put forward expert judgment. The data was collected during focus group discussion. ANP's pairwise comparison also embeded with potential errors related to transitivity. Checking processes in the ANP process is done by maitaining inconsistency to a value less than $10 \%$. 


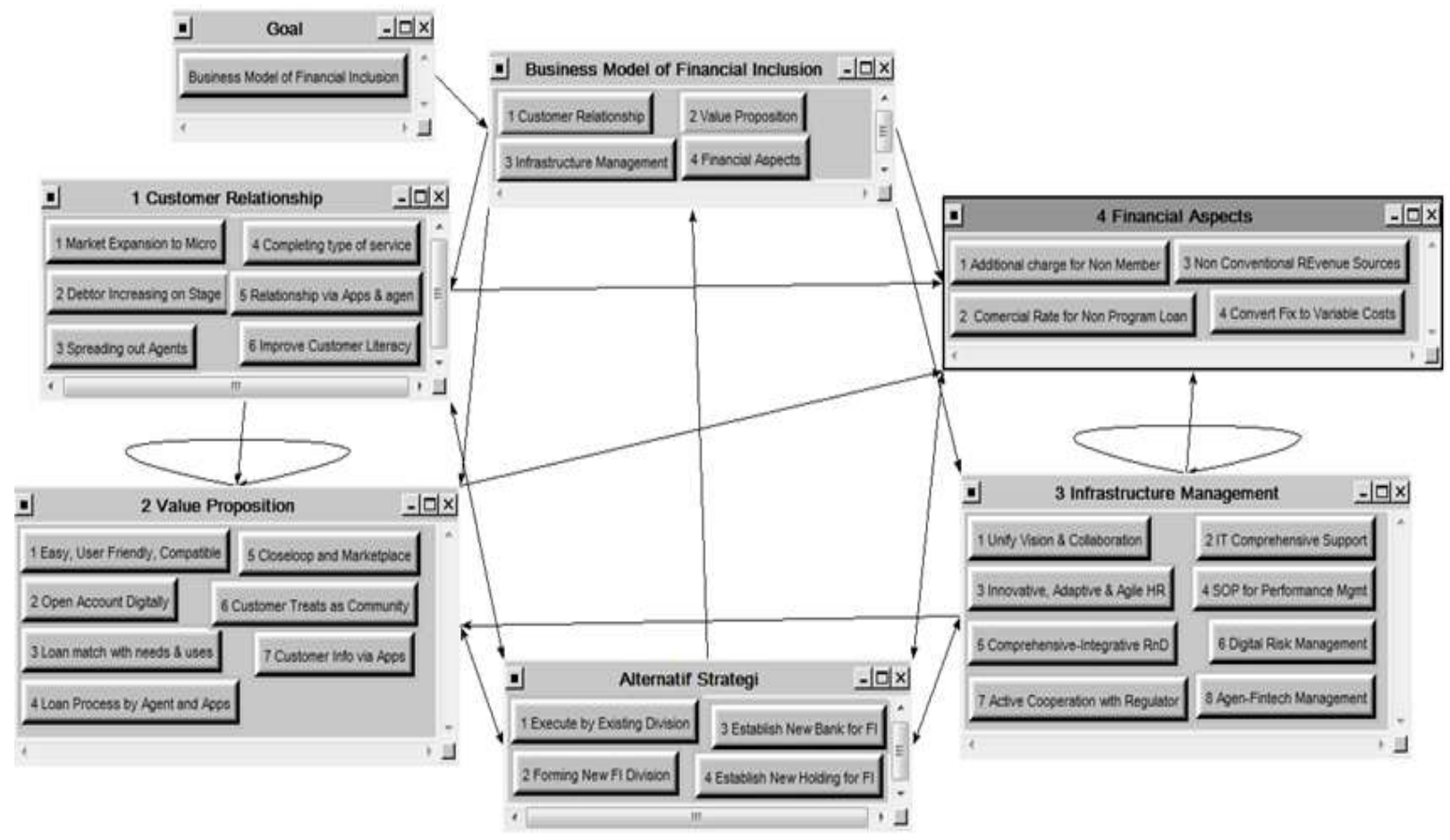

Figure 2. Structure of ANP

Each cluster in the ANP structure comprises sub-elements listed as strategy mapped on the business model canvas, as follows:

1. Customer Relationship contains of: (1) expansion to micro market (2) debtor increasing on stages, (3) spreading out agents, (4) completing type of service, (5) relationship via Apps and agents, and (6) improve customer literacy.

2. Value Proposition, contains of: (1) easy, user-friendly, and compatible, (2) open account digitally, (3) loan match with uses and needs, (4) loan processed by agent and Apps, (5) closed loop and marketplace, (6) customer treats as community, and (7) customer info via apps.

3. Infrastructure Management contains of: (1) unify vision and collaboration, (2) IT comprehensive support, (3) Innovative, adaptive and agile HR, (4) SOP for performance management, (5) comprehensive and integrative R\&D, (6) Digtal risk management, (7) active cooperation with regulator, and (8) agents and fintech management.

4. Financial Aspects contains of: (1) additional charge for non member, (2) commercial rate for non program loan, (3) non-conventional revenue sources, and (4) convert fix to variable costs.

Whereas alternative strategy is a cluster outside the business model canvas, the cluster contains sub-elements of strategy choice for the implementation of a business model. This cluster contains implementation strategies: (1) execute by existing division, (2) forming new financial inclusion division, (3) establish a new bank for financial inclusion, (4) establish new holding for financial inclusion. The ANP process output is a prioritizing strategy in implementing business models as a whole.

\section{RESULTS AND DISCUSSION}

\subsection{ISM Results}

The results of ISM processing on the "requirements" element consist of the power-dependence driving matrix and the structural model is shown in Figure 3. From the analysis of the elements of "requirements" there are two key sub-elements that act as leverage points in the system, i.e: (E1) the similarity of vision and collaboration between Units, and (E9) opportunity to benchmark, and the availability of relevant knowledge and ideas. The success of meeting the requirements of sub-elements E1 and E9 will drive the success other sub-elements. The sub-element E6, E10 and E8 are dependent on other sub-elements. 

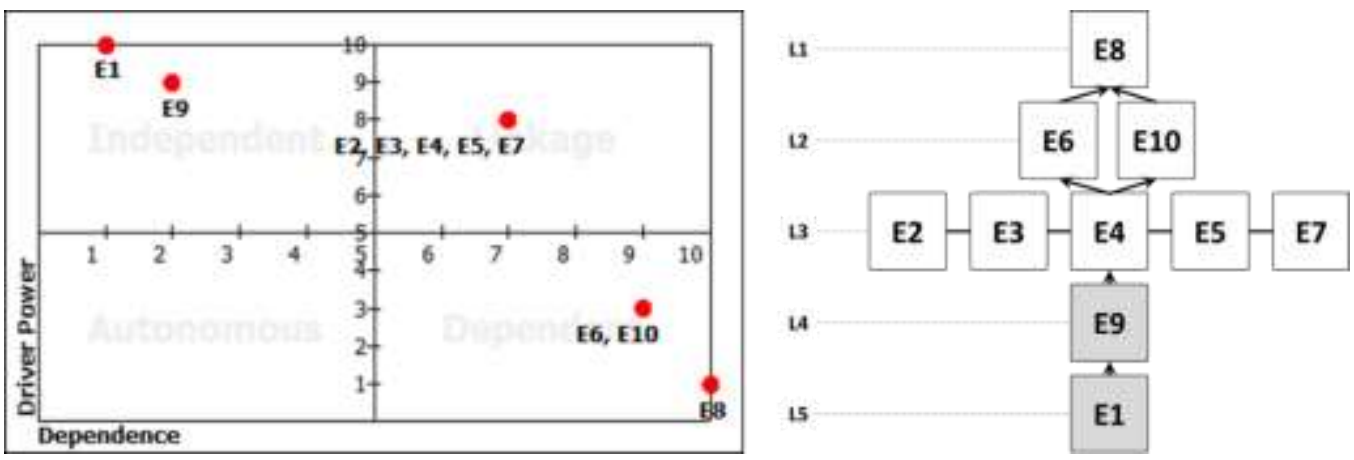

Figure 3. Driving Power-Dependence Matrix and Structural Model for Element of "Requirements"

The results of ISM on the "constraints" element consist of the power-dependence driving matrix and the structural model is shown in Figure 4. From the analysis of the elements of "constrains" there is only one key sub-element that act as leverage point in the system, i.e (E12) information technology support that has not been optimal for all kind of services. The success of avoiding the constrains of sub-element E12 will drive the success other sub-elements. The sub-element E1, E2, E13 and E11 are dependent on other sub-elements.
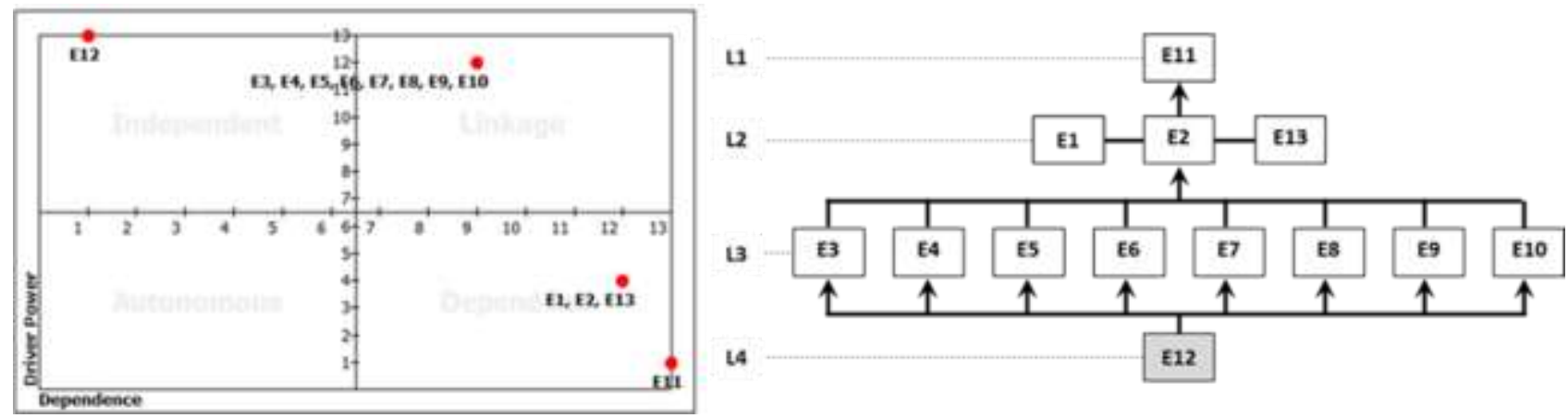

Figure 4. Driving Power-Dependence Matrix and Structural Model for Element of "Constraints"

The results of ISM on the "objectives" element consist of the power-dependence driving matrix and the structural model is shown in Figure 5. From the analysis of the elements of "objectives" there is only one key sub-element that act as leverage point in the system, i.e (E1) meets customer expectations (easy to reach, cheap, fast, and not complicated). The success of fulfilling the objective of sub-element E1 will drive the success other sub-elements. The other sub-elements are dependent on E1 sub-element.

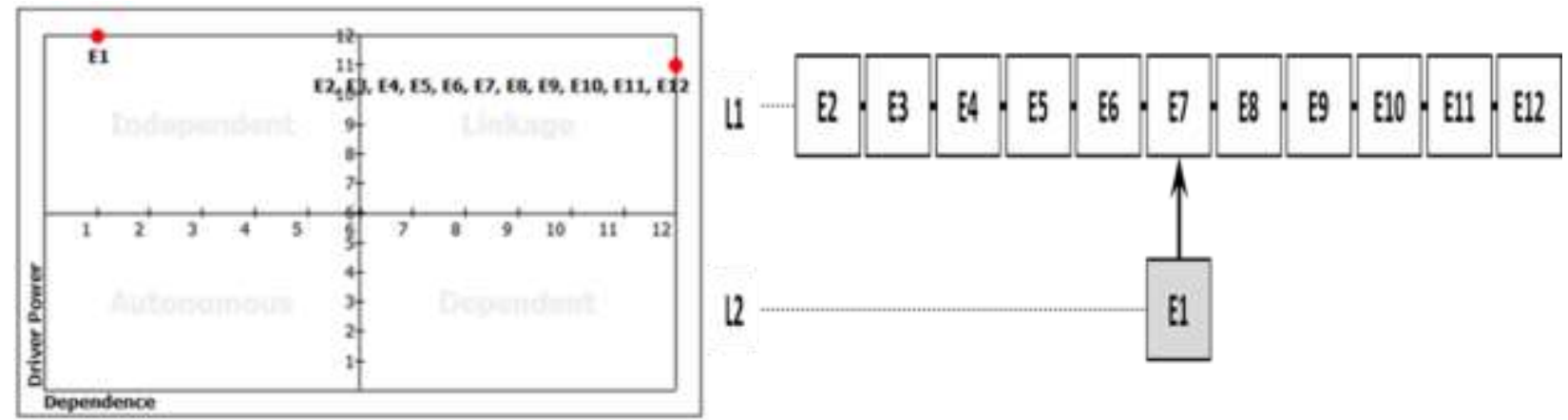

Figure 5. Driving Power-Dependence Matrix and Structural Model for Element of "Objectives"

The results of ISM on the "possible changes" element consist of the power-dependence driving matrix and the structural model is shown in Figure 6. From the analysis of the elements of "possible changes" there are four key sub-elements that act as leverage points in the system, i.e: (E1) encourages the equalization of vision and coordination and collaboration between Units, (E2) establishes SOPs of recognition of performance and fair key performance indicators, (E3) specifies the terms of revenue / cost sharing, and (E4) elimination of silo mentality. The success of making changes on of subelement E1, E2, E4 and E3 will drive the success other sub-elements. The other sub-elements are dependent on subelements of E1, E2, E4 and E3. 

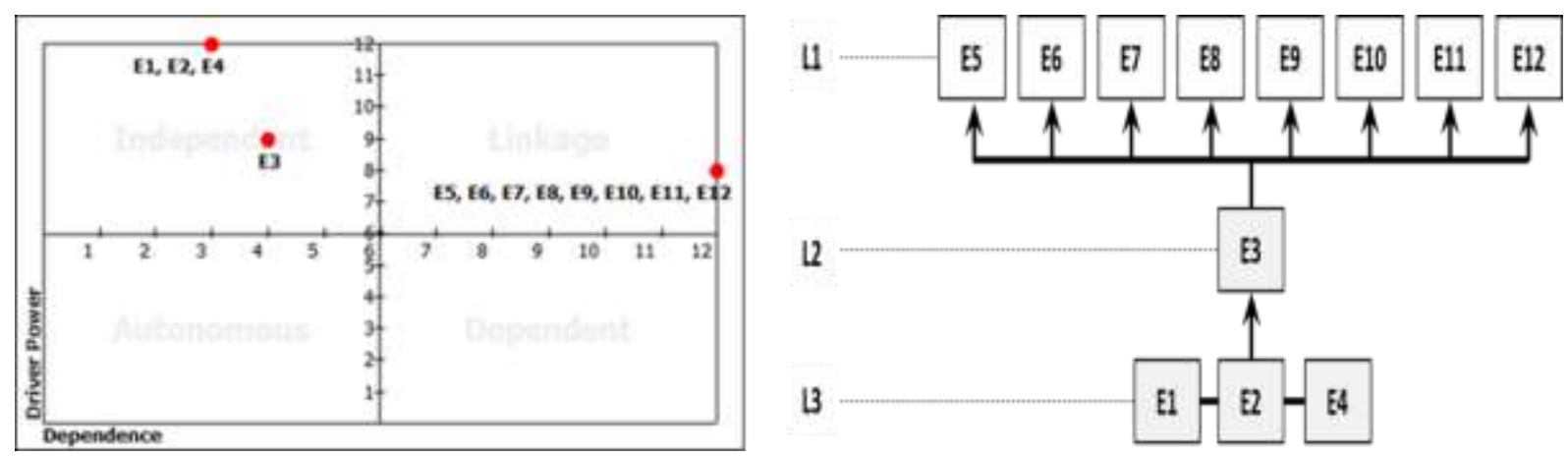

Figure 6. Driving Power-Dependence Matrix and Structural Model for Element of "Possible Changes"

The results of ISM on the "actors" element consist of the power-dependence driving and the structural model is shown in Figure 7. From the analysis of the elements of "actors" there are four key sub-elements that act as leverage points in the system, i.e: (E1) Directors, (E10) Government / Ministry, (E11) Regulators, and (E14) Customers. The success of driving on of sub-element E1, E10, E11 and E14 will drive the success other sub-elements. The sub-elements of E9, E13 and E12 are dependent on the other sub-elements. Sub-element of E10, E11 and E14 are uncontrolable by the company, what it can do is influencing them.
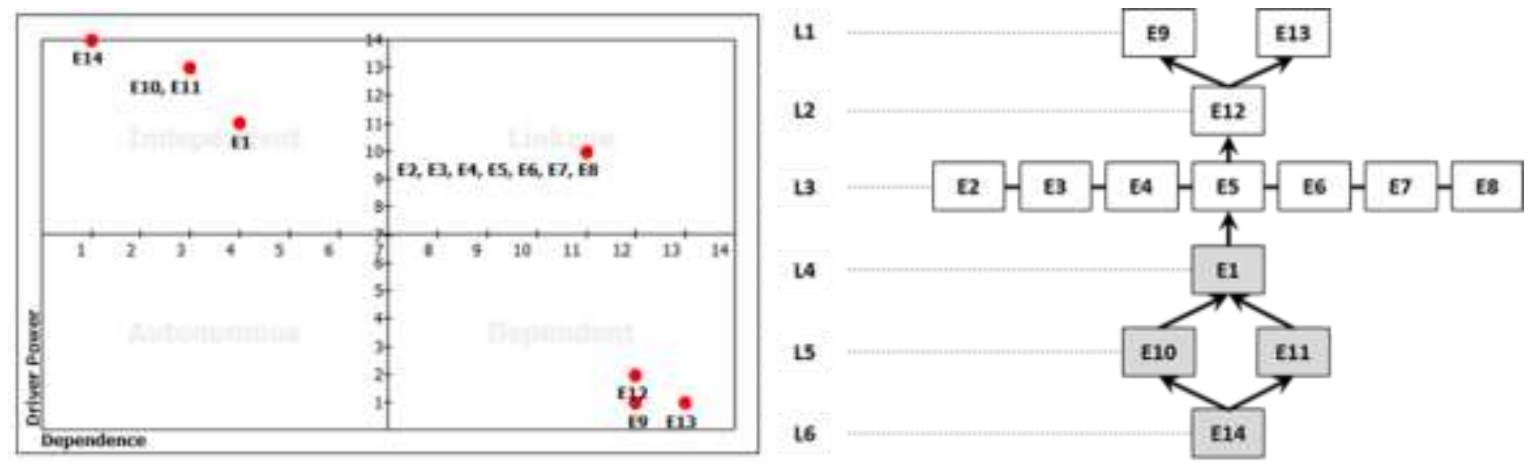

Figure 7. Driving Power-Dependence Matrix and Structural Model for Element of "Actors"

\subsection{ANP Results}

The ANP process was carried out by software called Super Decision 2.8. Following recommendations of [19], each pairwise comparison group is controlled by its transitivity with a maximum inconsistency level of $10 \%$. The result of ANP is a list of sub-elements prioritization. Since the ANP analysis carried out on a comparation between sub-elements in one cluster, then the prioritization is shown graphically for each cluster. 

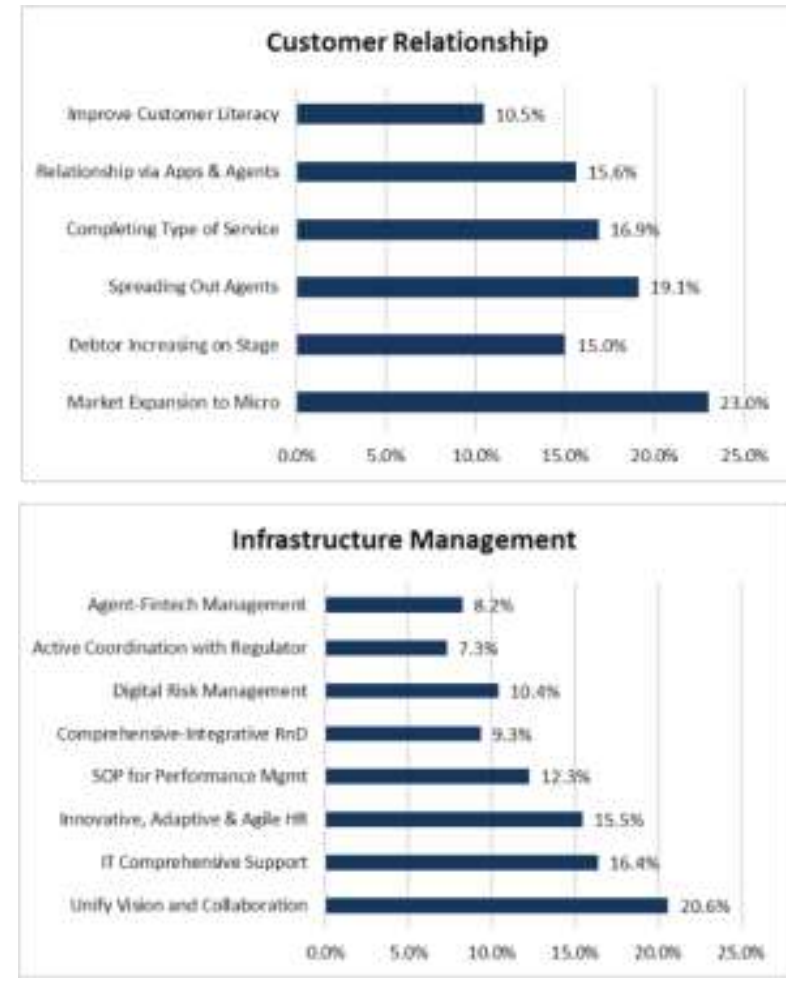
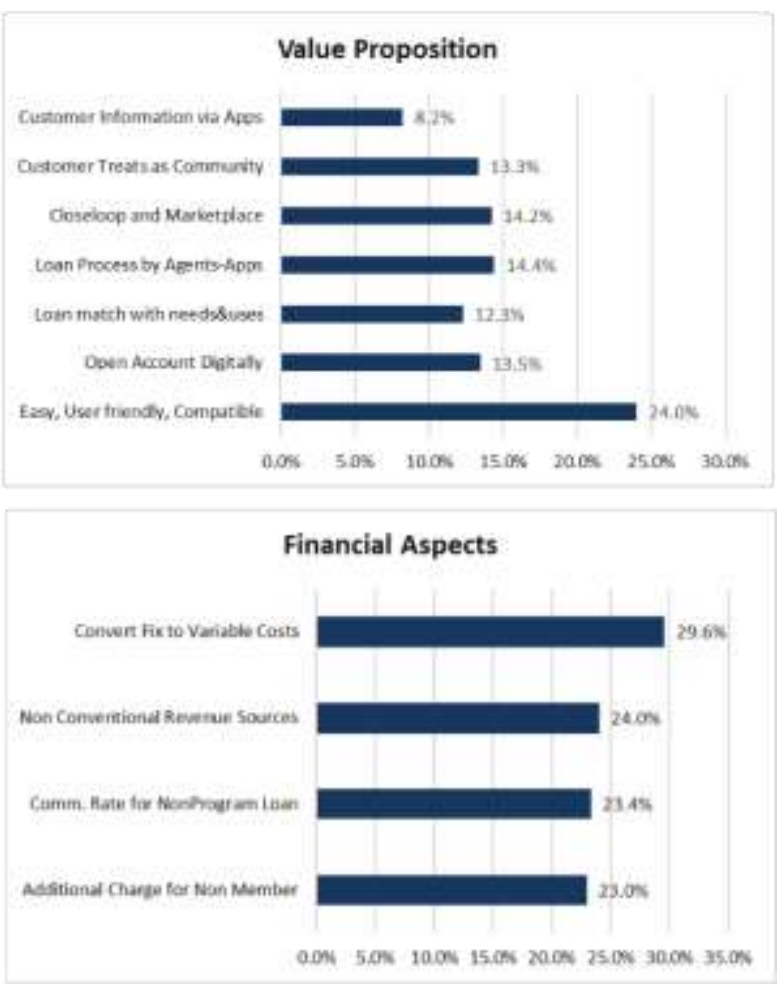

Figure 8. Prioritization for Clusters in Business Model Canvas
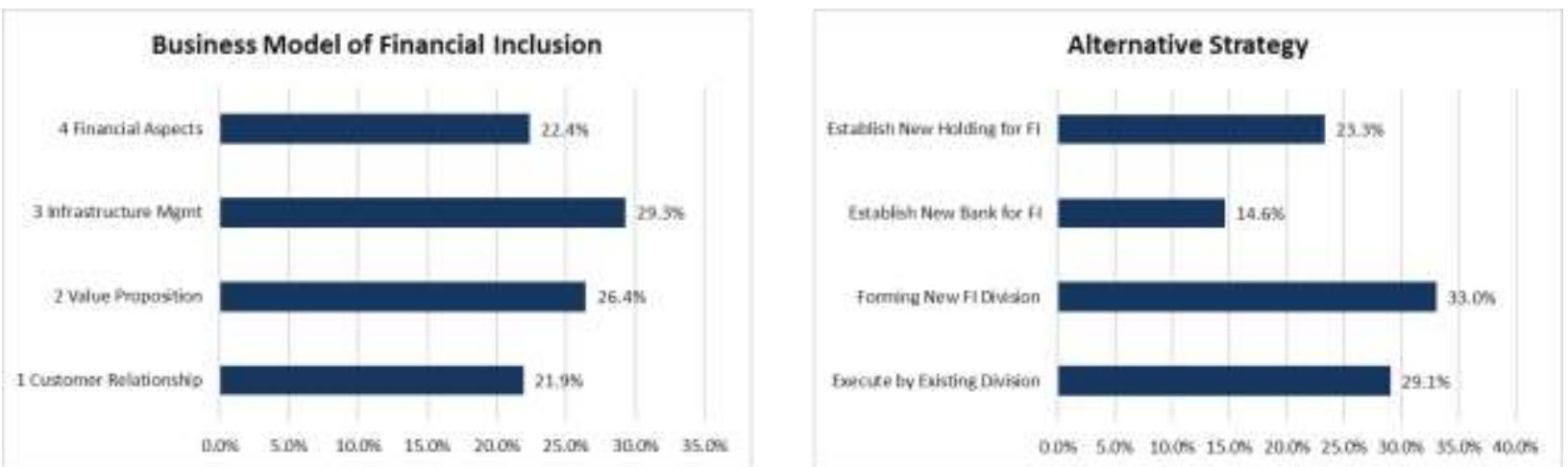

Figure 9. Prioritization for Business Model FI and The Alternative Strategies

Prioritization of each cluster as the result of ANP is illustrated in Figure 8 and Figure 9. The main priorities in each cluster are as follows:

1. Customer Relationship Cluster. Contains the main priority of "expansion to micro market" with weight in one cluster of $23.0 \%$, followed by "spreading out agents" (19.1\%), and "completing type of service" (16.9\%)

2. Cluster Value Proposition. Contains top priority "easy, user-friendly, and compatible" with weight in one cluster of $24.0 \%$, far above the next priority, i.e. "loan processed by agents and Apps" (14.4\%), and "closed loop and marketplace" (16.9\%)

3. Cluster Infrastructure Management. Contains the main priority of "Unify vision and collaboration" with a weight in one cluster of $20.6 \%$, slightly above the next priority, i.e. "IT comprehensive support" (16.4\%), and "Innovative, adaptive and agile HR" $(15.5 \%)$

4. Cluster Financial Aspects. Contains top priority "convert fix to variable costs" with weight in one cluster of $29.6 \%$, followed by "non-conventional revenue sources" $(24.0 \%)$.

5. Among the 4 clusters above, the main priority is Infrastructure Management $(29.3 \%)$.

6. Cluster Alternative Strategy choose the strategy for "forming new financial inclusion Division" weighing $33.0 \%$.

The findings from the ISM analysis in the form of critical sub-elements and the contribution ANP in the form of prioritizing sub-elements elucidate the same direction and mutually reinforcing. In general, some literature discusses the similar verdict, [9] suggests that business models have to describe cost/revenue architecture and perspective on how to do business. Experts agree by prioritizing a strategy of "convert fix to variable costs" and "non-conventional revenue sources". 
The strategy produced is also in line with [23], who predict the future of the financial services industry. His findings such as a shift in customer preferences, the importance of meeting customer needs, digitizing financial services, IT support, the role of agents and financial applications, the importance of innovation, and collaboration with regulators. Among [23] findings "collaboration with regulators" categorized as a low priority. It seems the experts consider that regulations must be accepted and implemented as they are, while the role of the company is more about how to anticipate these regulations.

In terms of the implementation of a model or project, one of the most common perspectives is "doing the easiest that has the greatest impact". Experts agree that forming a new division to manage financial inclusion is the best strategy. Through gathering activities in a new division, i.e. decision making, execution and risk mitigation, processes become easier and faster. Furthermore, by establishing a new division, neither forming a new bank nor a new financial entity, then the legal complexity and non-financial problems can be eliminated.

According to the results of ISM and ANP analysis, implementation strategy of the business model shown in figure 1. can be determined.The output of ISM and ANP analysis, that shows an in line results each other, further strengthens the confidence level to the implementation strategy that will be decided.

\subsection{Manajerial Implication.}

The bank's strategic planning unit will highly benefit from this research, especially in the area of strategic implementation. Having the capability of strategic implementation prioritizing, banks can execute their business models more accurately according to the availability of resources. Banks can also find out the most optimal leverage point of the business model, so that the plan can be executed effectively.

\section{CONCLUSION AND RECOMMENDATION}

Using ISM methodology on the framework of business model canvas, experts agree that the development and implementation of financial inclusion business model must be focused on: (1) requirement aspects, (2) constrain aspects, (3) objectives aspects, (4) the aspects of possible changes, and (5) aspects of actors. Good understanding on these aspects will lead to a successful process.

These two methods bring recommendations in the same direction in developing business model implementation strategies. The combination of the key sub-elements of ISM and the prioritization of the ANP are mutually reinforcing. It can be concluded that the business model execution strategy is "forming a new division to manage financial inclusion". Furthermore, the key factors that will play a significant role and need to be prioritized in the implementation consist of:

1. building a common vision and stimulate collaboration between units,

2. IT comprehensive support,

3. meet customer needs, and anticipate their pain and gain, such as loan process by agents or apps, and spreading out the agents,

4. expand loan market to micro segment

5. encourage benchmark and capture new knowledge or ideas,

6. prepare the rules of revenue/cost sharing, and eliminate silo mentality

7. convert fix cost to variable cost and build non conventional revenue

8. enhance directors' role to maintain customers, as well as paying attention to government and regulators.

\section{REFERRENCES}

[1] Honohan P, King M, "Cause and Effect of Financial Access: Cross Country Evidence from the Finscope Surveys", IIIS Discussion Paper No 399, 2012.

[2] Honohan P, "Cross-Country Variation in Household Access to Financial Services", Prepared for the World Bank Conference on Access to Finance, Washington DC, 2007.

[3] Tambunan T, "Financial Inclusion, Financial Education, and Financial Regulation: A Story from Indonesia”, ADBI Working Paper No 535, Asian Development Bank Institute, Tokyo, 2015.

[4] World Bank, The Little Data Book on Financial Inclusion, The World Bank, Washington DC, 2015.

[5] Demirguc-Kunt A, Klapper L, "Measuring Financial Inclusion: Explaining Variation in Use of Financial Services Across and within Countries", Brookings Paper on Economic Activity, Vol.44, issue 1, 279-340, 2013.

[6] Benouna G, Tkiouat M, "Studies and Research on Microfinance Sector in Morocco: An Overview",Asian Journal of Applied Sciences, Vol 4, Issue 3, 2016.

[7] Sani AI, Hassan S, "International Remittances and GDP Growth in Nigeria", Asian Journal of Applied Sciences, Vol.3 Issue 3, 2015.

[8] Sikari N, Harikrishnan K, "M-Banking Payment Service Model Concepts", Asian Journal of Applied Sciences, Vol.5 Issue 3, 2017. 
[9] Zott C, Amit R, Massa L, “The Business Model: Recent Developmet and Future Research”, Journal of Management 2011 37:1019-1042, 2011.

[10] Magretta J, “Why Business Models Matter”, Harvard Business Review, Vol. 80 No. 5, pp. 86-92, 2002.

[11] Xi Y, Zhang X, "Mastering Chinese Business Model by Conducting Indigenous Management Research", Chinese Management Studies, Vol. 7 No. 3, 2013, pp. 337-343, 2013.

[12] Edi WS, Marimin, Daryanto A, Saptono IT, "Pengembangan Model Bisnis Bank "X" dalam Mendukung Inklusi Keuangan Menggunakan Kerangka Kerja Soft System Methodology (SSM)”, MIX Jurnal Ilmiah Manajemen, Vol.9 No 1, 2019.

[13] Osterwalder A, Pigneur Y, Business Model Generation: A Handbook for Visionaries, Game Changers, and Challengers, John Wiley and Sons, Inc, Hoboken, New Jersey, 2010.

[14] Warfield JN, "Developing Subsystem Matrices in Structural Modeling, IEEE Transactions on Systems, Man, and Cybernetics", Volume: SMC-4 , Issue: 1, 1974.

[15] Marimin, Teknik dan Aplikasi Pengambilan Keputusan Kriteria Majemuk, PT Penerbit PT Gramedia Widiasarana Indonesia, Jakarta, 2004.

[16] Vinodh S, Ramesh K, Arun CS, “Application of Interpretive Structural Modelling for Analysing the Factors Influencing Integrated Lean Sustainable System”, Clean Techn Environ Policy (2016) 18:413-428, 2016.

[17] Attri R, Dev N, Sharma V, "Interpretive Structural Modeling (ISM) approach: An Overview", Research Journal of Management Sciences, Vol. 2(2), 3-8, 2013.

[18] Saaty TL, Vargas LG, Decision Making with the Analytic Network Process, Economic Politic Social and Technological Aplication with Benefits Opportunities Costs and Risks, Second Edition, Springer, New York, 2006.

[19] Saaty TL, "The Analytic Network Process", Iranian Journal of Operation Research, Vol.1, Issue 1 (5-2008), 2008.

[20] Saxena JP, Sushil, Vrat P, "Hierarchy and Clasification of Program Plan Element Using Interpretive Structural Modeling: A Case Study of Energy Conservation in the Indian Cement Industry”, Systems Practice, Vol.5 No 6, 1992, Plenum Publishing Corporation, 1992.

[21] Ascarya, Gunadi W, Cahyono W, Anwar E, Syarifuddin F, "Strategi Meningkatkan Preferensi Perbankan Syariah Indonesia Dalam Menggunakan Pembiayaan Bagi Hasil", Jurnal Ekonomi dan Bisnis Islami, FEB - Universitas Padjadjaran, Vol. 4, No. 1, June, 2014,

[22] Osterwalder A, "The Business Model Ontology", A Proposition in Design Science Approach, Diplome Postgrade en Information et Organisation (DPIO) de l'Ecole des HEC des l'Universite de Lausanne, 2004.

[23] McWaters RJ, "The Future of Financial Services: How Disruptive Innovations are Reshaping the Way Financial Services are Structured, Provisioned and Consumed", Financial Service Community in Collaboration with Deloitte, World Economic Forum, 2015. 